\title{
Ecophysiology and nutrition of cabezona pineapple (Ananas comosus L. Merril) in Chontalpa, Tabasco, Mexico
}

\author{
F. E. Murillo-Hernández, F.E. ${ }^{1}$; Córdova-Sánchez, S. ${ }^{2 *}$; Salgado-García, S. ${ }^{3}$; \\ Valerio-Cardenas, G. ${ }^{2}$; Bolio-López, G.I. ${ }^{2}$; Hernández-Villegas, M.M. ${ }^{2}$; \\ Almenares-López, D. ${ }^{2}$; Sánchez-Gutiérrez, F. ${ }^{1}$; Pérez-Romero, J. $^{3}$; Morales-Guzmán, G. ${ }^{2}$ \\ 1 Universidad Autónoma de Chiapas-Escuela Maya de Estudios Agropecuarios, Carretera Catazajá-Palenque \\ Km. 4, C.P. 29980, Catazajá, Chiapas, México. \\ 2 Universidad Popular de la Chontalpa, División Académica de Ciencias Básicas e Ingenierías, CA-QVyDS, \\ Carretera Cárdenas-Huimanguillo, Km. 2.0 Cárdenas, Tabasco, México. CP. 86500. \\ 3 Colegio de Postgraduados-Campus Tabasco, Grupo MASCA.A-LPI-2: AESS, Km. 3.5 Periférico Carlos A. \\ Molina S/N. H. Cárdenas, Tabasco, CP 86500, México. \\ * Correspondence: sacorsa_1976@hotmail.com
}

Gitation: Murillo-Hernández, F. E., Córdova-Sánchez, F.E., SalgadoGarcía, S., Valerio-Cardenas, C.2; Bolio-López, G.I.2; HernándezVillegas, M.M.2; Almenares-López, D.2; Sánchez-Gutiérrez, F. 1; PérezRomero, J.3; Morales-Guzmán, G.2 (2021). Ecophysiology and nutrition of cabezona pineapple (Ananas comosus L. Merril) in Chontalpa, Tabasco, Mexico. Agro Productividad. https://doi.org/ 10.32854/agrop.v14il1.2026

Editor in Chief: Dr. Jorge Cadena Iñiguez

\section{Received: May 5, 2021.}

Accepted: October 14, 2021.

Published on-line: November 26, 2021.

This work is licensed under a Creative Commons Attribution-NonCommercial 4.0 International license.

\begin{abstract}
Objective: To improve the nutrition of the pineapple (Ananas comosus) cultivation using fertilizers.

Design/Methodology/Approach: The Sistema Integrado para Recomendar Dosis de Fertilizantes (SIRDF) established the fertilization doses for pineapple in the Cutanic Acrisol (Endoclayic, Hyperdystric, Ferric) (ACct(ncehdfr)) - N(230kg)-P(183kg)-K(300kg) - and Cutanic Acrisol (Endoclayic, Ferric) (ACct(ncefr)) $-\mathrm{N}(253 \mathrm{~kg})-\mathrm{P}(138 \mathrm{~kg})-\mathrm{K}(360 \mathrm{~kg})$ - soil sub-units. The SIRDF doses were compared with the control dose (producer): $\mathrm{N}(85 \mathrm{~kg}), \mathrm{P}(85 \mathrm{~kg})$, and $\mathrm{K}(85 \mathrm{~kg})$.

Results: The fruits harvested from the ACct(ncehdfr) soil to which the SIRDF dose was applied were larger ( $\mathrm{cm}$, without the crown), heavier ( $\mathrm{kg}$, with and without the crown), and also had higher ${ }^{\circ}$ Brix values compared with control. This was not the case for the crown, which was heavier when the producer dose was applied. Meanwhile, the produce harvested from the ACct(ncefr) soil to which the SIRDF dose was applied included taller plants $(\mathrm{cm})$, larger fruits $(\mathrm{cm}$, with crown), larger crowns $(\mathrm{cm})$, wider fruits ( $\mathrm{cm}$, circumference), heavier fruits ( $\mathrm{kg}$, with and without crown), and higher ${ }^{\circ}$ Brix values; on the contrary, the crowns were heavier $(\mathrm{kg})$ in control.

Study Limitations/Implications: Yield and fruit quality observations are affected by the quality of the Cabezona pineapple vegetable materials, agronomic management, and the attack of citrus mealybugs.

Findings/Conclusions: The fruits produced using the SIRDF doses had lower ${ }^{\circ}$ Brix than the Cayena Lisa and MD pineapples. A 56-58 $\mathrm{t} \mathrm{ha}^{-1}$ volume of fruit can be produced. This study proves that the doses established by the SIRDF had positive results for the improvement of the Cabezona pineapple production in Tabasco, Mexico.
\end{abstract}

Key words: Cabezona pineapple, fertilizer dose, acid soils.

\section{INTRODUCTION}

Although fertilizers have been used for two centuries, and their use is based on the chemical nutrition of plants, they have had a great impact in the increase of production 
and the quality of food. Additionally, this enhanced production has led to an increase in the return on invested capital rate for the production systems (Finck, 1992). All agricultural production systems (short-, medium-, and long-term) must use fertilizers in order to maintain crop yield, particularly, when the whole plant is removed from the production system (Salgado and Núñez, 2012). Pineapple crops (Ananas comosus) are not the exception, particularly in Mexico, where these crops are only grown in acid soils. These soils are characterized by their high phosphorous fixation, zinc and boron deficiency, low ammonium and nitrates formation, low calcium, magnesium, and potassium content, and high aluminum saturation (Pastrana et al., 1998; Salgado et al., 2007). These fertility limiting conditions impact the pineapple yield and quality.

Fertilizer doses can be applied to pineapple crops; however, they are only applied to the MD2 and the Cayena Lisa cultivars. These cultivars are grown for commercial purposes (supermarkets, exportation), while the Cabezona pineapple is sold only in regional markets. The Instituto Nacional de Investigaciones Forestales, Agrícolas y Pecuarias (INIFAP) has developed technologies for the main or most important cultivars. However, it has not established a definitive dose; instead, it recommends applying two or three times the N12P8-K12-Mg4 mix (25 g per plant on the soil) and 15 applications of 2.5\% DAP (18-46-00) (on the leaves) to the MD2 cultivar (Uriza, 2011).

In Tabasco, Mexico, a definitive dose has not been established. Only the doses generated by SIRDF in 2010 — as a result of the study carried out by the Colegio de Postgraduados, Campus Tabasco - are available. Appropriately applying the dose of each nutriment is necessary for the nutrition of the Cabezona pineapple; currently, the producers nurture the crops based on their own experience (Salgado et al., 2010; Salgado et al., 2017a). Therefore, this study validated two fertilization doses for two soils sub-units of the savannah of Humanguillo.

\section{MATERIALS AND METHODS}

\section{Experimental Plots Location}

Two simultaneous experiments were carried out, using the vegetative material known as hijuelos or gallos (basal shoots); these experiments were carried out in two communities of Huimanguillo, Tabasco: Ejido La Esperanza and Salvador Neme Castillo. These communities are located in La Chontalpa, the second most important region after the Pedregales area. The first plot was established at the UTM X 431955 and Y 1980750 coordinates, at a 24 masl altitude. The second plot was located at the UTM X 434073 and Y 1979811 coordinates, at a 27 masl altitude. Both plots were established on soils were Cabezona pineapple had been grown for more than 10 years.

\section{Experimental Plots}

Two fertilization treatments were established in each community: T1, the dose of the producer and T2, the dose established by SIRDF (Salgado et al., 2010). Both treatments were established using a completely randomized design with three repetitions.

In La Esperanza, the experiment was carried out in a $60 \times 65 \mathrm{~m}\left(3900 \mathrm{~m}^{2}\right)$ plot, owned by Mr. Candelario Gómez Torres. The planting distance was $130 \mathrm{~cm}$ between rows and 
$25 \mathrm{~cm}$ between plants, which generated a population density of 11,999 plants. In Salvador Neme Castillo, the experiment was carried out in a $70 \times 75 \mathrm{~m}\left(5250 \mathrm{~m}^{2}\right)$ plot, owned by Mr. Edilberto de la Cruz Osorio. The planting distance was $130 \mathrm{~cm}$ between rows and $25 \mathrm{~cm}$ between plants, which generated a population density of 16,152 plants.

\section{Soil Sampling}

Samples were taken from both plantations. Six sub-samples were taken from each experimental plot, using a stainless-steel earth sampler: three samples were taken from the space between the plants and the other three were taken from the alleys. These samples were placed in a bucket. Afterwards, the six samples were homogenized and a $1.5 \mathrm{~kg}$ sample was taken. The sampling depth was $0-30 \mathrm{~cm}$. The samplings were dried in the shade for 20 days, and then they were ground and filtered with 0.5 - and 2-mm sieves. Once sieved, they were sent to the soil laboratory of the Colegio de Postgraduados - Campus Montecillo, where their physical and chemical properties were determined.

\section{Fertilizer Doses Application}

Pineapple plants have high soil nutrient demands. This condition explains the sharp yield drop in plots that have been sown for many years without agronomical management or the use of fertilizers (Montilla et al., 1997). SIRF recommends the following fertilizer doses for pineapple crops (Salgado et al., 2010; Salgado et al., 2017a):

N230kg - P183kg - K300kg. La Esperanza.

N253kg - P138kg - K360kg. Salvador Neme Castillo.

These doses were those recommended for the Cutanic Acrisol (Endoclayic, Hyperdystric, Ferric) and Cutanic Acrisol (Endoclayic, Ferric) soil sub-units in La Esperanza and Salvador Neme Castillo, respectively (Salgado-García et al., 2017b). The DAP, UREA, and KCI sources were used to apply the fertilizer doses. The mixes were prepared after their ingredients were weighted. The producer applies a $500 \mathrm{~kg}$ dose of triple 17 (i.e., $85 \mathrm{~kg}$ of N, $85 \mathrm{~kg}$ of $\mathrm{P}$, and $85 \mathrm{~kg}$ of K). Once the dose was obtained, it was applied to the crop.

\section{Plant (Height) and Fruit (Length and Diameter) Measurement}

The plants that showed optimal harvesting conditions were measured. Thirty plants (10 small, 10 medium, and 10 large fruits) were measured. These plants were chosen according to the harvesting characteristics established by the producer (size, color, and texture of the fruit). Once the plants were selected and cut, the following measurements were taken: height of the plant, diameter and length of the fruit (with and without crown), and height of the crown.

\section{Plant and Fruit Weight and ${ }^{\circ}$ Brix}

Once the 30 selected pineapples were measured, they were weighted in a common $50-\mathrm{kg}$ scale. We weighted the complete plant (with and without fruit), the fruit (with and 
without crown), and, finally, the crown. A steel bodkin juice extractor was used to obtain samples in order to determine the ripeness of the fruit. The bodkin was introduced into each selected pineapple; the juice was extracted and it was placed on a handheld refractometer to measure the ${ }^{\circ}$ Brix.

\section{Statistical Analysis}

The 9.3 SAS System statistical package software was used to carry out a completely randomized design ANOVA and a Tukey comparison test for all the variables.

\section{RESULT AND DISGUSSIONS}

\section{Analysis of the Macro and Microelements of the Soils}

The soils where the experiments were carried out had a strongly acid $\mathrm{pH}(\leq 5.0)$, zero salinity effects, a low exchange capacity, high organic matter content, rich nitrogen content, medium phosphorus content, low potassium, calcium, and magnesium content, and marginal to deficient micronutrient (iron, copper, zinc, and manganese) content (Table 1 and 2) (NOM- 021, 2001).

\section{Agronomic Characteristics of Pineapple Gultivation in Cutanic Acrisol (Endoclayic, Hyperdystric, Ferric) Soil (ACct(ncehdfr))}

According to the variance analysis and a Tukey comparison test, there were no significative differences in the agronomic variables evaluated for Cabezona pineapples: plant height, fresh plant weight, height of the fruit with crown, crown height, and fruit circumference (diameter) (Table 3). These variables had 6.64-26.33 coefficients of variation. The average plant height was similar — with no significative difference - to the height recorded by García et al. (2006) for this cultivar grown in the hillsides of Monagas and Sucre, Venezuela.

The fruit and the crown account for 39.74 and $60.26 \%$ of the total height, respectively. These results are similar to the findings about this cultivar reported by García et al. (2006). In general terms, the circumference (diameter) of this barrel-shaped fruit was greater than the $13.23 \mathrm{~cm}$ diameter reported by García et al. (2006), who also reported $10.58{ }^{\circ}$ Brix for total soluble solids, a higher ${ }^{\circ}$ Brix value than the one reported for the SIRDF dose.

Meanwhile, there were significative differences for the following variables: height of the fruit without crown, total weight of the fruit with crown or whole fruit, weight of the fruit without crown, crown weight, and ${ }^{\circ}$ Brix. These variables showed $10.33-27.43 \%$ coefficients of variation.

Based on this difference, the fruit (with and without crown) was heavier with the SIRDF dose, while the crown was heavier with the producer dose. In the case of both doses, their results were higher than those founds by García et al. (2006), who recorded 2.28, 2.03, and $0.25 \mathrm{~kg}$ for each of these variables. Likewise, the fruit accounts for $87.24 \%$ of the total weight; this figure is similar to the $89.03 \%$ reported by García et al. (2006). Meanwhile, the crown accounts for $12.76 \%$ of the total fruit weight. In general terms, approximately 53 and $60.75 \mathrm{t} \mathrm{ha}^{-1}$ of Cabezona pineapple - fresh fruit without crown and fruit with crown - can be produced in Cutanic Acrisol (Endoclayic, Hyperdystric, Ferric) soil; Pérez-Romero et al. 
(2020) report a similar yield. The SIRDF dose seems to have had a positive impact in the fresh fruit yield in these savannah soils located in Huimanguillo, Tabasco.

\section{Agronomic Characteristics of Pineapple Gultivation in Cutanic Acrisol (Endoclayic, Ferric) Soil (ACct(ncefr))}

Based on the results presented in Table 4 and according to the variance analysis and the Tukey comparison test (0.05), there were significative differences in the following variables: plant height, height of the fruit with crown, crown height, fruit circumference (diameter), weight of the whole fruit with crown, weight of the fruit without crown, crown weight, and ${ }^{\circ}$ Brix. These variables had a $6.18-19.60 \%$ coefficient of variation. The weight of the plant and height of the fruit without crown variables did not show significative differences. In general terms, the coefficient of variation had a $28.67-11.15 \%$ fluctuation - variations in the measurement of variables that are usually expected in every fieldwork.

The tallest plants $(126.65 \mathrm{~cm})$ were obtained with the application of the SIRDF dose; these results match the findings of García et al. (2006) who published that Cabezona pineapples achieve an average height of approximately $125 \mathrm{~cm}$ and an average weight of approximately $2.83 \mathrm{~kg}$. The fruits to which the producer's dose was applied had bigger crowns and consequently were taller than those to which the SIRDF dose was applied. Without the crown, the fruit had an average height of $17.13 \mathrm{~cm}(35 \%$ of the fruit's total height). These results match the findings of García et al. (2006). The biggest crowns were obtained with the dose applied by the producer based on his experience; therefore, this dose had a greater effect on the size of the crown than on the size of the fruit; additionally, the crown accounts for $64 \%$ of the total fruit height.

The longest circumference (diameter) was obtained with the SIRDF dose. This means that these Cabezona pineapples had a $16.34 \mathrm{~cm}$ diameter. This result is greater than the results obtained by García et al. (2006), who recorded hillside-grown pineapples with a 13.23 diameter.

The highest weight for whole fruits (fruit with crown) was obtained applying the dose established by SIRDF. That result was higher than the findings of García et al. (2006) who recorded a $2.28 \mathrm{~kg}$ weight. Likewise, the application of the SIRDF dose resulted in the heaviest fruits without crown; this accounts for $86 \%$ of the full weight of the whole fruit (fruit with crown). These results are higher than the findings of García et al. (2006) who recorded $2.03 \mathrm{~kg}$ results.

The crown was heavier and bigger when the producer's dose was used. Likewise, it accounts for $14 \%$ of the total fruit weight. In general terms, the fruit weight percentage was lower than the percentages recorded by García et al. (2006), who determined that the fruit without crown accounts for $89 \%$ of the weight of the whole fruit (fruit with crown). The whole fruits and the fruits without crowns had yields of 67.25 and $58.25 \mathrm{tha}^{-1}$ in Cutanic Acrisol (Endoclayic, Ferric) soil, respectively. These results were higher than those obtained in Cutanic Acrisol (Endoclayic, Hyperdystric, Ferric) soil.

The dose applied with the SIRDF methodology resulted in higher total soluble soils ( ${ }^{\circ}$ Brix) than the producer dose. These results are lower than those found by García et al. (2006), who recorded $10.58{ }^{\circ}$ Brix for Cabezona pineapples grown in the hillsides of the 
States of Monagas and Sucre, Venezuela. Therefore, this genetic material is more acid that the Cayena Lisa and MD2 materials which are edible or 100\% market-oriented.

\section{CONGLUSIONS}

There were significative differences in the following characteristics of Cabezona pineapples grown in Cutanic Acrisol (Endoclayic, Hyperdystric, Ferric) (ACct(ncehdfr)) soil compared to control: height of the fruit without crown, total fruit weight, weight of the fruit without crown, crown weight, and ${ }^{\circ}$ Brix. There were significative differences in Cutanic Acrisol (Endoclayic, Ferric) soils for the following variables: plant height, height of the fruit with crown, crown height, fruit circumference, total fruit weight, weight of the fruit without crown, crown weight, and ${ }^{\circ}$ Brix. Up to $56-58 \mathrm{t} \mathrm{ha}^{-1}$ of fresh fruit can be produced. Fruits produced with the SIRDF dose had lower ${ }^{\circ}$ Brix than Cayena Lisa and MD cultivars.

\section{AGKNOWLEDGMENTS}

The authors would like to thank the producers for their cooperation and the PRODEP for funding the SAyF/ DA/013/2016 "Aprovechamiento sustentable del cultivo de piña (Ananas comosus L. merril) en México" project, which funded the Green Chemistry and Sustainable Academic Body UPCH-10 of the Universidad Popular de La Chontalpa.

\section{REFERENGES}

Finck, A. (1985). Fertilizantes y fertilización: Fundamentos y métodos para la fertilización de los cultivos. Editorial REVERTÉ, S.A. España. 439 p.

García, M., Salcedo, F., Barrios, R., y Carrera, L. (2006). La piña “pilón” o cabezona cultivada en las laderas de los estados de Monagas y Sucre. Revista de difusión de tecnología agrícola, pecuaria, pesquera y acuícola. INIA Divulga 7: 27-29.

Montilla, B.I., Fernández, S., Alcalá, De M.D., y Gallardo, M. 1(997). El cultivo de la piña en Venezuela. Maracay, Ven. FONAIAP-CIAEL. IICA/CREA/PROCIANDINO/FRUTHEX. 155 p.

Murillo-Hernández, F.E., Córdova-Sánchez, S., Salgado-García, S., Bolio-López, G.I., De la Cruz-Burelo, P., y Sánchez-Gutiérrez, F. (2019). Determinación nutrimental de piña criolla (Ananas comosus L. Merril) en la sub-región de la Chontalpa Tabasco, México. Agroproductividad 12(7): 31-34. DOI https://doi. org/10.32854/agrop.v0i0.1472

Norma oficial mexicana 021- secretaria de Medio Ambiente y Recursos Naturales (NOM-021-RECNAT. 2001). Que establece las especificaciones de fertilidad, salinidad y clasificación de suelos. Estudios, muestreo y análisis. Secretaría de Medio Ambiente y Recursos Naturales. Norma Oficial Mexicana NOM-021-REGNAT-2001. 75 p.

Pastrana. L.A., Rodríguez, G.M., León, A.I.E., y Ramírez, D.G. (1995). Manual de producción de naranjo en suelos ácidos de Tabasco. INIFAP-CIRGOG-CAEHUI-ISPROTAB. Villahermosa, Tabasco. 30 p.

Pérez-Romero, J., Salgado-García, S., Córdova-Sánchez, S., del Carmen Lagunes-Espinoza, L., \& OrtizGarcía, C. F. (2020). Evaluación de parámetros de crecimiento en piña "cabezona" (Ananas comosus (L.) Merr.) en respuesta a la fertilización NPK. AgroProductividad 13(8): 3-9. DOI https://doi.org/10.32854/ agrop.vi.1797

Salgado, G.S., y Núñez, E.R. (2012). Manejo de fertilizantes y abonos orgánicos. Editorial-Colegio de Postgraduados-Mundi Prensa, México, D.F. 146 p.

Salgado, G.S., Palma, L.D.J., Zavala, G.J., Ortiz, G.C.F., Lagunés, E.L.C., Castelán, E.M., Guerrero, P.A., Ortiz, C.A.I., and Córdova, S.S. (2017a). Integrated system for recommending fertilization rates in pineapple (Ananas comosus (L.) Merr.) crop. Acta Agronomica 66(4): 566-573. http://dx.doi.org/10.15446/ acag.v66n4.62257

Salgado, G.S., Palma, L.D.J., Zabala, G.J., Lagunes, E.L.C., Castelán, E.M., Ortiz, G.C.F., Ventura, U.F., Marín, A.Á., Moreno, G.E., y Rincón, R.J.A. (2007). Sistema integrado para recomendar dosis de fertilizantes en las plantaciones de cítricos de Tabasco, México. Colegio de Postgraduados - Campus Tabasco. H Cárdenas, Tabasco. 89 p. 

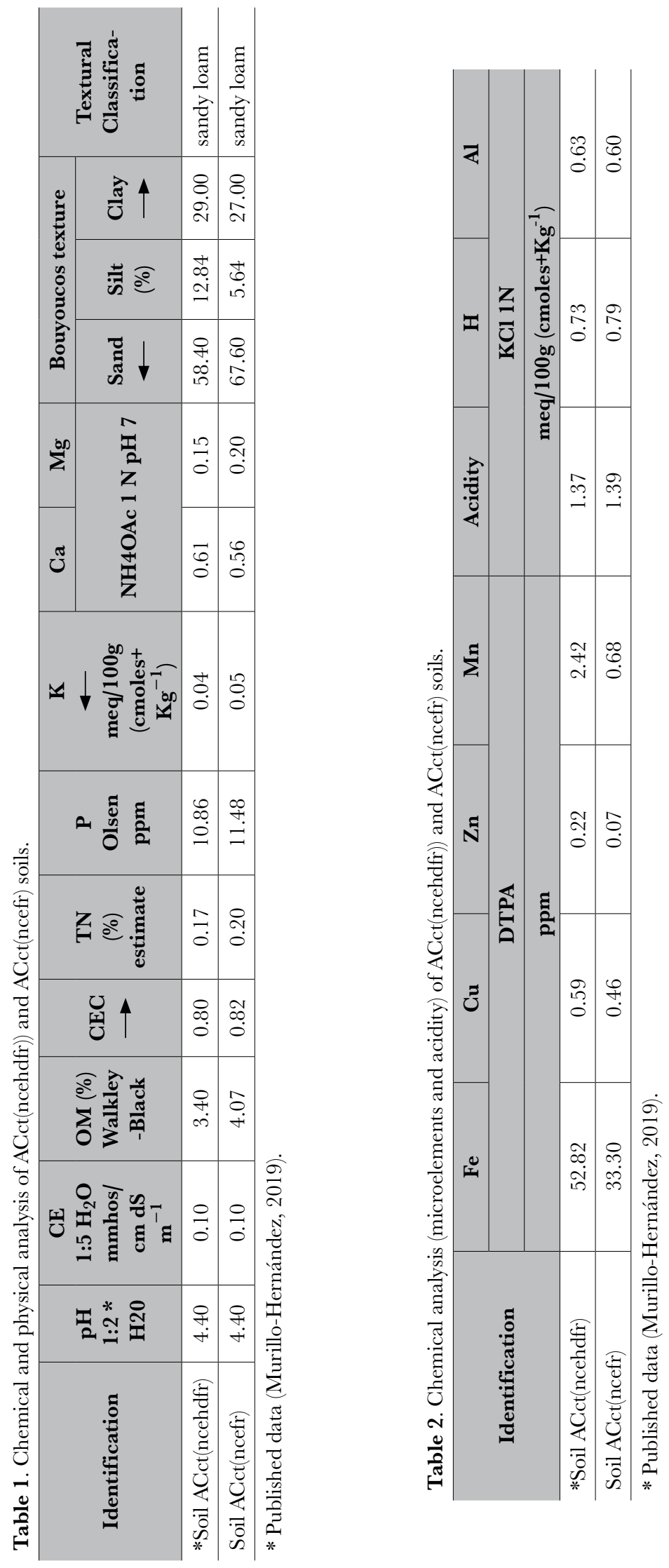

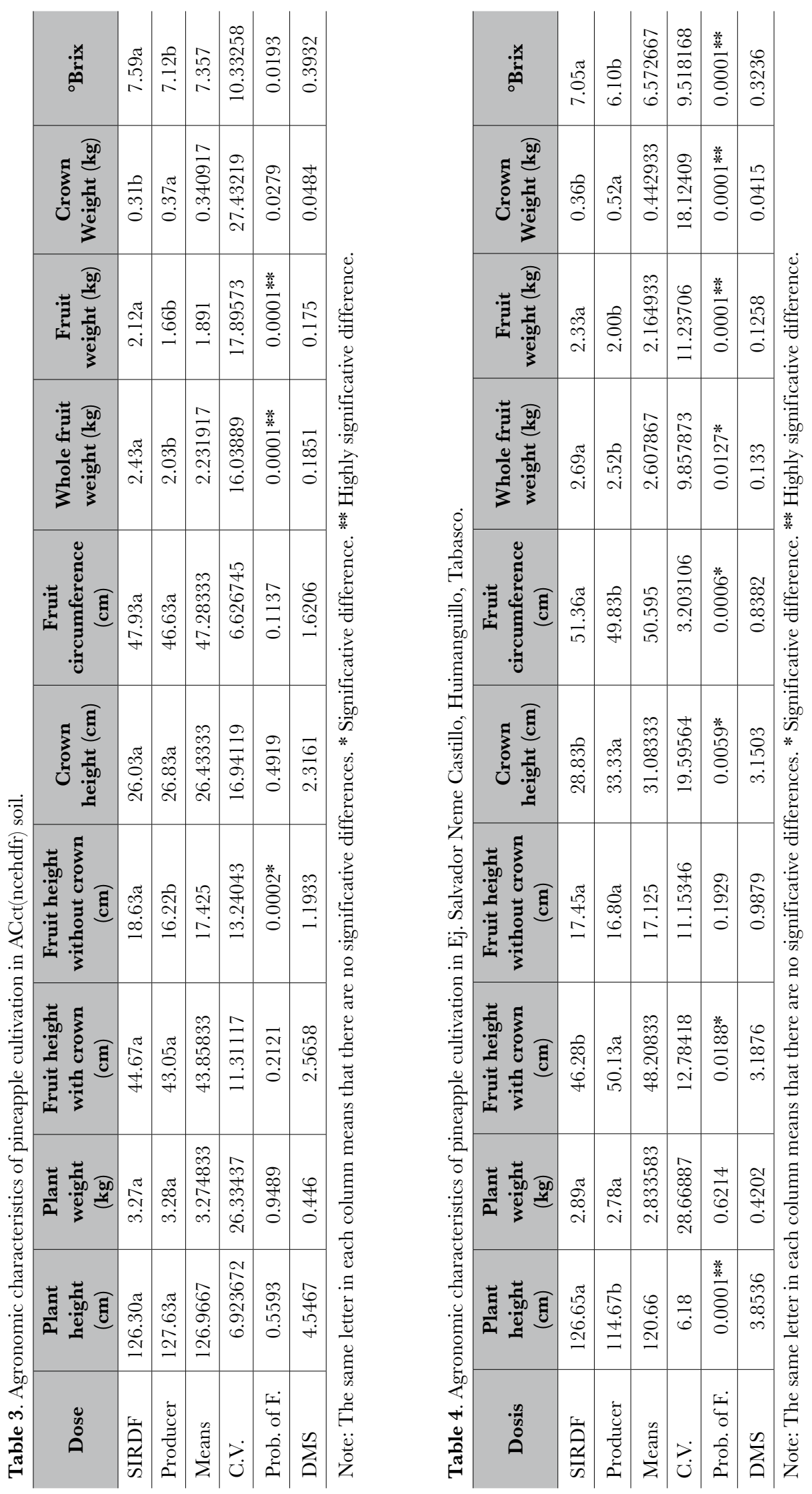
Salgado, G.S., Palma-López, D.J., Zabala-Cruz, J., Ortiz, L.H., Castalan-Estrada, M., Lagunes-Espinoza, L.C., Guerrero-Peña, A. y Córdova-Sánchez, S. (2010). Sistema integral para recomendar dosis de fertilizantes (SIRDF): en la zona piñera de Huimanguillo, Tabasco. Colegio de Postgraduados Campus Tabasco, H. Cárdenas, Tabasco, México. 81 p.

Salgado-García, S., Palma-López, D.J., Zavala-Cruz, J., Ortiz-García, C.F., Lagunes-Espinoza, L.C., OrtizCeballos, A.I., Córdova-Sánchez, S. y Salgado-Velázquez, S. (2017b). Los suelos ácidos de la sabana de Huimanguillo, Tabasco, México. Agroproductividad, 10(12): 16-21.

Uriza, Á.D.E. (2011). Paquete Tecnológico Piña MD2 (Ananas comosus var. comosus): Establecimiento y mantenimiento. Centro de Investigación Regional Golfo Centro. Campo Experimental Cotaxtla / Papaloapan (INIFAP). Isla, Veracruz. 16 p. 